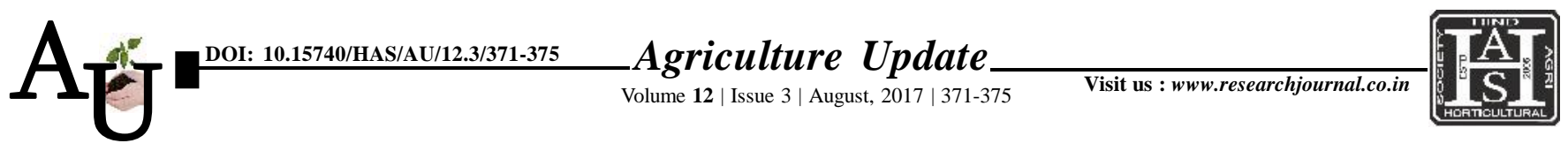

- e ISSN-0976-6847

\title{
Research Article: Knowledge of vermiculture technology among the rural women: A case of Rajasthan
}

\author{
MAYA KUMARI JAT AND B.C. BOCHALYA
}

Article Chronicle : Received :

07.04.2017;

Revised :

14.06.2017;

Accepted :

28.06.2017

Key WoRds:

Vermiculture

technology, Rural

women, Knowledge

SUMMARY : The research study was carried out in Bikaner district. Bikaner Panchayat Samiti was selected purposely due promotion of organic farming in DBT project. Two villages Bharupuwa and Husangsar were selected purposively; as these villages are under DBT project and vermiculture technology was promoted in them. For the study total 120 respondents were selected. Pre-structured interview schedule was used for data collection. The major findings of the present study revealed that the overall knowledge of respondents was medium. Out of five aspects, the knowledge about the aspect of basic knowledge was very good than other aspect.

How to cite this article : Jat, Maya Kumari and Bochalya, B.C. (2017). Knowledge of vermiculture technology among the rural women: A case of Rajasthan. Agric. Update, 12(3): 371-375; DOI : 10.15740/HAS/AU/12.3/371375.

Author for correspondence :

\section{MAYA KUMARI JAT}

Krishi Vigyan Kendra

(J.A.U.), NANA-

KANDHASAR (GUJARAT)

INDIA

Email:rewar.maya@gmail.

com

See end of the article for

authors' affiliations 